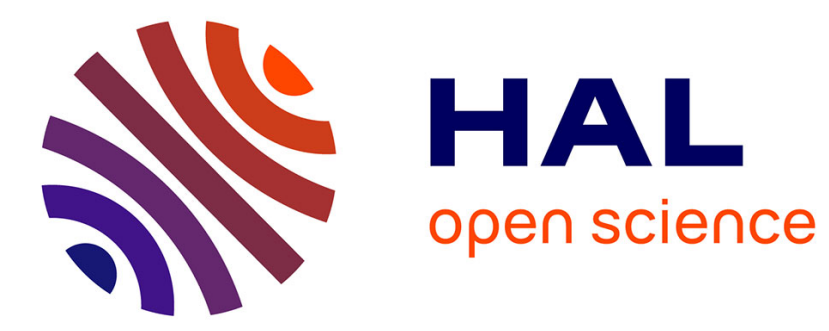

\title{
Corrigendum to "Overcoming the challenges of phage therapy for industrial aquaculture: A review" [Aquaculture 513 (2019) 734423]
}

\author{
Antoine Culot, N. Grosset, Michel Gautier
}

\section{To cite this version:}

Antoine Culot, N. Grosset, Michel Gautier. Corrigendum to "Overcoming the challenges of phage therapy for industrial aquaculture: A review" [Aquaculture 513 (2019) 734423]. Aquaculture, In press, 513, pp.734423. 10.1016/j.aquaculture.2019.734851 . hal-03131660

\author{
HAL Id: hal-03131660 \\ https://hal.inrae.fr/hal-03131660
}

Submitted on 4 Feb 2021

HAL is a multi-disciplinary open access archive for the deposit and dissemination of scientific research documents, whether they are published or not. The documents may come from teaching and research institutions in France or abroad, or from public or private research centers.
L'archive ouverte pluridisciplinaire HAL, est destinée au dépôt et à la diffusion de documents scientifiques de niveau recherche, publiés ou non, émanant des établissements d'enseignement et de recherche français ou étrangers, des laboratoires publics ou privés.

\section{(ㅇ)(1) $\$$}

Distributed under a Creative Commons Attribution - NonCommercial - NoDerivatives $\mid 4.0$ 
Corrigendum

\section{Corrigendum to "Overcoming the challenges of phage therapy for industrial aquaculture: A review" [Aquaculture 513 (2019) 734423]}

\section{A. Culot*, N. Grosset, M. Gautier}

Microbiology Laboratory, Agrocampus Ouest, Institut National de la Recherche Agronomique (INRA), UMR 1253 Science and Technology of Milk and Eggs (STLO), Rennes, France

The authors regret the following errors, which appeared in the article during the review process:

On page 9, Section 4.1.1 "Ecological significance of marine bacteriophages", the correct figure for the average concentration in surface coastal waters is $10^{7}$ phage-like particles per millilitre, and not 107 .
On page 10, the correct version of Table 1 is as follows (the "Performance" column is the only one that contained errors):

Table 1: Examples of phage administration approaches considered for aquaculture.

The authors would like to apologise for any inconvenience caused.

\begin{tabular}{|c|c|c|c|c|c|c|c|}
\hline Pathogen & Farmed species & MOI & Challenge & Phages used & Performance & Administration & Reference \\
\hline Aeromonas salmonicida & Solea senegalensis & 100 & Immersion & AS-A & Mortality drop from $36 \%$ to $0 \%$ & Immersion & Silva et al (2016à). \\
\hline Lactococcus garvieae & Seriola quinqueradiata & 0,1 & Injection & $\mathrm{PlgY}$ & Mortality drop from $90 \%$ to $45 \%$ & Injection & Nakai et al (199). \\
\hline Lactococcus garvieae & Seriola quinqueradiata & 0,1 & Reverse gavage & $\mathrm{PlgY}$ & Mortality drop from $65 \%$ to $10 \%$ & Feed pellets & Nakai et al. (1999) \\
\hline Pseudomonas plecoglossicida & Plecoglossus altivelis & 1 & Feed pellets & $\begin{array}{l}\text { PPpW-3 } \\
\text { PPpW-4 }\end{array}$ & Mortality drop from $65 \%$ to $22 \%$ & Feed pellets & Park et al. (2000) \\
\hline Pseudomonas plecoglossicida & Plecoglossus altivelis & & $\begin{array}{l}\text { Contaminated } \\
\text { fish }\end{array}$ & $\begin{array}{l}\text { PPpW-3 } \\
\text { PPpW-4 }\end{array}$ & Mortality drop from $90 \%$ to $26 \%$ & Feed pellets & Park and Nakai (2003) \\
\hline Pseudomonas aeruginosa & Clarias gariepinus & & & & $\begin{array}{l}\text { Diameter of lesion diminishes } \\
\text { from } 15 \mathrm{~mm} \text { to } 5 \mathrm{~mm}\end{array}$ & Swabbing & Khairnar et al. (2013) \\
\hline Streptococcus iniae & Paralichthys olivaceus & & Injection & $\begin{array}{l}\text { PSiJ31 } \\
\text { PSiJ32 PSiJ4 } \\
\text { PSiJ42 }\end{array}$ & Mortality drop from $80 \%$ to $0 \%$ & Injection & Matsuoka et al. (2007) \\
\hline Vibrio anguillarum & Salmo salar & 1 & Immersion & CHOED & Mortality drop from $95 \%$ to $30 \%$ & Immersion & Higuera et al. (2013) \\
\hline Vibrio anguillarum & Salmo salar & 20 & Immersion & CHOED & Mortality drop from $95 \%$ to $0 \%$ & Immersion & Higuera et al. (2013) \\
\hline Vibrio harveyi & Panaeus monodon & & $\begin{array}{l}\text { Natural occur- } \\
\text { ence }\end{array}$ & $\begin{array}{l}\text { Viha10 } \\
\text { Viha8 }\end{array}$ & $\begin{array}{l}\text { Mortality drop from } 88 \% \text { to } 32 \% \\
\text { compared to antibiotic treat- } \\
\text { ment }\end{array}$ & Immersion & $\begin{array}{l}\text { Karunasagar et al. } \\
(2007)\end{array}$ \\
\hline
\end{tabular}

DOI of original article: https://doi.org/10.1016/j.aquaculture.2019.734423

* Corresponding author.

E-mail address: a.culot@hotmail.fr (A. Culot). 